\title{
Apatite and Chitin Amendments Promote Microbial Activity and Augment Metal Removal in Marine Sediments
}

\author{
Jinjun Kan ${ }^{1 *}$, Anna Obraztsova ${ }^{2}$, Yanbing Wang ${ }^{3}$, Jim Leather ${ }^{2}$, Kirk G. Scheckel ${ }^{4}$, \\ Kenneth H. Nealson ${ }^{3}$, Y. Meriah Arias-Thode ${ }^{2 *}$ \\ ${ }^{1}$ Stroud Water Research Center, Avondale, USA \\ ${ }^{2}$ SPAWAR Systems Center-Pacific, San Diego, USA \\ ${ }^{3}$ Department of Earth Sciences, University of Southern California, Los Angeles, USA \\ ${ }^{4}$ National Risk Management Research Laboratory, Environmental Protection Agency, Cincinnati, USA \\ Email: ${ }^{*} j k a n @$ stroudcenter.org, meriah.ariasthode@navy.mil
}

Received May 4, 2013; revised June 12, 2013; accepted June 19, 2013

Copyright (C) 2013 Jinjun Kan et al. This is an open access article distributed under the Creative Commons Attribution License, which permits unrestricted use, distribution, and reproduction in any medium, provided the original work is properly cited.

\begin{abstract}
In situ amendments are a promising approach to enhance removal of metal contaminants from diverse environments including soil, groundwater and sediments. Apatite and chitin were selected and tested for copper, chromium, and zinc metal removal in marine sediment samples. Microbiological, molecular biological and chemical analyses were applied to investigate the role of these amendments in metal immobilization processes. Both apatite and chitin promoted microbial growth. These amendments induced corresponding bacterial groups including sulfide producers, iron reducers, and phosphate solubilizers; all that facilitated heavy metal immobilization and removal from marine sediments. Molecular biological approaches showed chitin greatly induced microbial population shifts in sediments and overlying water: chitin only, or chitin with apatite induced growth of bacterial groups such as Acidobacteria, Betaproteobacteria, Epsilonproteobacteria, Firmicutes, Planctomycetes, Rhodospirillaceae, Spirochaetes, and Verrucomicrobia; whereas these bacteria were not present in the control. Community structures were also altered under treatments with increase of relative abundance of Deltaproteobacteria and decrease of Actinobacteria, Alphaproteobacteria, and Nitrospirae. Many of these groups of bacteria have been shown to be involved in metal reduction and immobilization. Chemical analysis of pore- and overlying water also demonstrated metal immobilization primarily under chitin treatments. X-Ray absorption spectroscopy (XAS) spectra showed more sorbed $\mathrm{Zn}$ occurred over time in both apatite and chitin treatments (from $9 \%-27 \%$ ). The amendments improved zinc immobilization in marine sediments that led to significant changes in the mineralogy: easily mobile $\mathrm{Zn}$ hydroxide phase was converted to an immobile $\mathrm{Zn}$ phosphate (hopeite). In-situ amendment of apatite and chitin offers a great bioremediation potential for marine sediments contaminated with heavy metals.
\end{abstract}

Keywords: Apatite; Chitin; Amendments; Marine Sediment; DGGE; Microbial Community; Copper; Zinc; Chromium

\section{Introduction}

In situ amendments have been shown as an effective approach to enhance removal of metal or organic contaminants under a variety of environments [1-6]. Currently, both inorganic and organic materials are widely used as promising sediment amendments; including geotextile mats, apatite, organoclay, and chitin. Inorganic amendments help to immobilize several toxic metals such as lead, zinc, and cadmium by forming stable compounds

${ }^{*}$ Corresponding author. that render the metals no longer bioavailable $[2,3,7]$. Organic amendments, in contrast, may induce indigenous microbes capable of bio-reduction and/or of direct or indirect immobilization of toxic metals $[1,4,8,9]$.

Apatite, an inorganic phosphate mineral, has been applied to facilitate the immobilization of several toxic metals including $\mathrm{Cu}, \mathrm{Zn}$ and $\mathrm{Pb}$ [10-12]. For example, apatite amendments have a long remedial history at metals contaminated soils sites $[10,13,14]$. Apatite's use in sediment remediation is more recent [15]. The DoD (Navy) is currently evaluating apatite amendments at a 
metal recycling facility to remediate high $\mathrm{Zn}$ levels in nearby sediments [16]. Phosphates released from apatite will sequester metals to form more stable metalphosphate complexes [3]. This process may be linked to activities of phosphate-solubilizing bacteria. Although marine environments are not phosphate-limited, recently Uzair and Ahmed [17] have successfully isolated both attached and free-living marine bacteria that were able to solubilize phosphate compounds when given suitable carbon sources.

Meanwhile chitin, a homopolymer of N-acetylglucosamine (NAG), is an abundant structural polysaccharide produced by many marine organisms. Several experiments have demonstrated that bacterial communities shift in response to amended chitin [18] and indigenous bacteria were capable of cleaving this polymer via the synthesis of specific enzymes that were induced by chitin [19]. Further, breakdown products (e.g. acetate and fructose) from chitin degradation may serve as ideal carbon sources for anaerobic and facultative microorganisms capable of metal reduction [20]. It is thus reasonable to expect that we hypothesize that amendment of apatite and/or chitin will stimulate bacterial growth, and subsequently enhance metal transition, immobilization and sequestration in marine environments.

Metabolically diverse indigenous microorganisms interact with metals in a variety of ways that lead to decreased metal solubility and mobility [21-22]. Among these microbes, iron-reducing and sulfide-producing bacteria (FeRB and SPB, respectively) are two biogeochemically important groups that have been shown to contain suitable physiology for metal precipitation and immobilization due to their metabolic end-products such as $\mathrm{Fe}(\mathrm{II})$ and $\mathrm{HS}^{-}$[23-29].

In addition to the effectiveness of bioremediation, one other critical perspective of inorganic or organic materials used as in situ amendment remediation alternatives, is to limit/avoid the impacts on living organisms. Therefore, during our primary study, we tested how the inorganic and organic amendments impacted microbial communities [30] and impacted the macro-invertebrate communities [31]. Dose-response experiments of candidate materials suggested that appropriate concentrations of apatite and chitin ( $5 \%$ and $0.5 \%$, respectively) amendments had little or no negative impacts on water quality and ambient living organisms [31].

In this study, apatite and chitin were applied to microcosms containing pristine, coarse, sandy sediments from Yaquina Bay (YB), Oregon, and contaminated, finegrained sediments from Mare Island (MI) Naval Shipyard, California, with and without spiked heavy metals. Responses of the microbial communities (biomass and population structures) were monitored in the treated sediments. Chemical analysis, including ICP-MS and X-ray absorption spectrometry was used to determine the ef- fects of the amendments on the sediment composition and zinc speciation.

\section{Experimental}

\subsection{Sediment Description}

Pristine and uncontaminated, sandy, coarse sediments from Yaquina Bay (YB), OR, and historically heavy metal contaminated, fine-grained sediments from Mare Island (MI) Naval Shipyard, CA, were evaluated [29]. Major properties of both sediments including percentage of silt/clay, TOC (total organic carbon), and metals were listed in a previous study [31]. Because the MI sediments were aged, additional spikes of $\mathrm{Cu}, \mathrm{Zn}$, and $\mathrm{Cr}$ were incorporated with the goal of metal concentrations in the overlying water of $\mathrm{Cu}=0.25 \mathrm{ppm}$, and $\mathrm{Zn}$ and $\mathrm{Cr}=1.0$ ppm (Table 1). These concentrations were used as a surrogate for current metal contaminated sites. The metal additions were added with the assumption of no binding as TOC of coarse sand is less than $0.1 \%$. The sediment types and treatments applied in this study are listed in Table 1.

\subsection{Amendment Experiments with Apatite and Chitin}

Mesocosm preparation and experimental setups followed previously described methods [30-31]. Briefly, for each treatment, $150 \mathrm{~g}$ of sediment was added to each of $5 \mathrm{rep}$ licate beakers. A sixth replicate was used for monitoring daily water. Approximately $750 \mathrm{~mL}$ of uncontaminated and filtered $(0.45 \mu \mathrm{m}$ Millipor filter) natural seawater (salinity at $30 \mathrm{psu}$ ) collected from near the mouth of San Diego Bay, was added to each jar. A 3-day equilibration period preceded the experiments. All beakers were gently and continuously aerated.

Based on the previous toxicological dose-response experiments and microbial response studies [30-31], apatite $(5 \%)$ and chitin $(0.5 \%)$ were selected as candidate amendment treatments. Concentrations of amendments and treatment setups are described in Table 1. Negative controls contained unspiked and unamended YB and MI sediments (Table 1; CUU and FUU, respectively).

\subsection{Microbiological Sample Collection and Analyses}

Water and sediment core samples were collected for all analyses at certain time points as required. Because many metal-microbe interactions occur in the overlying water and surface sediments, overlying water and pore-waters were analyzed for bacterial populations. Detailed descriptions of sample collections and treat ments are previously described [30]. Samples for molecular and microbiology analyses were collected at Day 0 and Day 28. 
Table 1. Sediment amendments applied in this study.

\begin{tabular}{lccc}
\hline $\begin{array}{c}\text { Sediment } \\
\text { type }\end{array}$ & Amendment & $\begin{array}{c}\text { Metal mixture* } \\
\text { spiking }\end{array}$ & $\begin{array}{c}\text { Experiment } \\
\text { abbreviation }\end{array}$ \\
\hline Coarse (YB) & Unamended & Unspiked & CUU \\
Coarse (YB) & Unamended & Spiked & CUS \\
Coarse (YB) & $5 \%$ apatite & Spiked & CAS \\
Coarse (YB) & $0.5 \%$ chitin & Spiked & CCS \\
Coarse (YB) & $5 \%$ apatite $+0.5 \%$ chitin & Spiked & CACS \\
Fine (MI) & Unamended & Unspiked & FUU \\
Fine (MI) & $5 \%$ apatite & Unspiked & FAU \\
Fine (MI) & $0.5 \%$ chitin & Unspiked & FCU \\
Fine (MI) & $5 \%$ apatite $+0.5 \%$ chitin & Unspiked & FACU \\
Fine (MI) & Unamended & Spiked & FUS \\
Fine (MI) & $5 \%$ apatite & Spiked & FAS \\
Fine (MI) & $0.5 \%$ chitin & Spiked & FCS \\
Fine (MI) & $5 \%$ apatite $+0.5 \%$ chitin & Spiked & FACS \\
\hline
\end{tabular}

YB: Yaquina Bay, OR; MI: Mare Island Naval Shipyard, CA; ${ }^{\text {Appropriate }}$ salt forms of $\mathrm{Cu}, \mathrm{Zn}$, and $\mathrm{Cr}$ were incorporated into the overlying water column to achieve free metal concentrations of $\mathrm{Cu}=0.25 \mathrm{ppm}$, and $\mathrm{Zn}$ and $\mathrm{Cr}=1.0 \mathrm{ppm}$.

\subsubsection{Microbiological Analysis}

Microbial biomass was determined by epifluorescence microscopy. DNA extraction, PCR-DGGE (denaturant gradient gel electrophoresis) of $16 \mathrm{~S}$ ribosomal RNA gene, band excision and sequencing, and phylogenetic analyses followed described protocols in a previous report [30].

\subsubsection{Clone Library Analysis}

Based on the fingerprinting results from PCR-DGGE, and to further characterize the bacterial communities from sediments, three clone libraries were constructed from the anaerobic zone on the treatments FUS, FCS, and FACS (Table 1). This analysis could not be completed from the coarse-grained sandy sediments because of insufficient DNA concentrations. Briefly, near full length of $16 \mathrm{~S} r$ RNA genes was amplified with primer 27 F-1492 R, and PCR products from triplicate samples were pooled to minimize variations. Then the amplicons were cloned using the TOPO TA Cloning Kit (Invitrogen) and then sequenced by using the Big Dye Terminator chemistry (Applied Biosystems). Chimeric sequences were detected using the program of Bellerophon [32] and removed from further analysis. All non-chimeric sequences were blasted against the GenBank (http://www.ncbi.nlm. nih.gov/genbank/). Sequences from both DGGE bands and clone libraries were submitted to GenBank under the accession number KF268681-KF268939.

\subsubsection{Phosphate Solubilizing Bacteria Detection}

Three dilutions $\left(10^{-1}, 10^{-2}\right.$, and $\left.10^{-3}\right)$ of overlying water and sediments (aerobic/anaerobic interface) were tested to detect phosphate-solubilizing bacteria on apatite agar plates. Plates were prepared as previously described [33] with some modifications, i.e. $6 \mathrm{~g} \mathrm{CaCl}_{2}$ and $4 \mathrm{~g} \mathrm{KH}_{2} \mathrm{PO}_{4}$ were added to $500 \mathrm{~mL}$ filtered $\left(0.22 \mu \mathrm{m}\right.$ Millipore $\left.{ }^{\mathrm{TM}}\right)$ seawater. To a separate $500 \mathrm{~mL}$ of sterile seawater, $10 \mathrm{~g}$ agar was added and all solutions were autoclaved separately. $20 \mathrm{~mL}$ of $1 \mathrm{M}$ sterile $\mathrm{NaOH}$ and $20 \mathrm{~mL}$ of $1 \mathrm{M}$ sterile glucose was added to the $\mathrm{CaCl}_{2} / \mathrm{KH}_{2} \mathrm{PO}_{4}$ seawater solution and mixed well. After that, the $\mathrm{CaCl}_{2} / \mathrm{KH}_{2} \mathrm{PO}_{4}$ seawater solution wasmixed with autoclaved agar solution and poured into plates. Diluted samples from the overlying water column and sediments were inoculated and streaked for isolation on the agar plates; incubated for 2 weeks at room temperature.

\subsection{Chemical Analyses}

Analyses for overlying and pore-water samples by ICPMS were taken at Day 0 and Day 10, due to the high microbial activity. Sediments were examined via X-ray absorption spectroscopy (XAS) at Day 0 and Day 10. To examine long-term effects of apatite, a few selected samples were analyzed at Day 28, and one sample from the unspiked apatite amendment was extended to 120 days.

\subsection{ICP-MS Analysis}

Metal extraction from overlying and pore-water followed EPA sample preparation protocol and metal analysis with ICP-MS were performed as previously described [34-35].

\subsection{X-Ray Absorption Spectroscopy (XAS)}

XAS analyses followed the exact protocol from a previous report [30]. Briefly, the samples were prepared as thin pellets with a hand operated IR pellet press and the samples were secured by Kapton tape. Five individual spectra for each sample were averaged followed by subtraction of the background through the pre-edge region using the Autobk algorithm and normalized to an atomic absorption of one. The data were converted from energy to photoelectron momentum ( $k$-space) and weighted by $k 3$. Identification of zinc phases in the sediment samples was accomplished by principal component analysis (PCA) and linear combination fitting (LCF) of the sediment XAS spectra relative to the known reference spectra. Reference materials examined include hopeite $\left(\mathrm{Zn}_{3}\left(\mathrm{PO}_{4}\right)_{2} \cdot 4 \mathrm{H}_{2} \mathrm{O}\right)$, $\mathrm{Zn}$-Al layered double hydroxide with nitrate and silicate interlayers, $\mathrm{Zn}(\mathrm{OH})_{2}, \mathrm{ZnO}$, sphalerite $(\mathrm{ZnS})$, zinc sorbed to ferrihydrite, zinc sulfate, aqueous zinc nitrate, franklinite $\left(\mathrm{ZnFe}_{2} \mathrm{O}_{4}\right)$, willemite $\left(\mathrm{Zn}_{2} \mathrm{SiO}_{4}\right)$, hemimorphite $\left(\mathrm{Zn}_{4} \mathrm{Si}_{2} \mathrm{O}_{7}(\mathrm{OH})_{2} \cdot \mathrm{H}_{2} \mathrm{O}\right)$, and gahnite $\left(\mathrm{ZnAl}_{2} \mathrm{O}_{4}\right)$. The accu- 
racy of LCF results was estimated to be $10 \%-15 \%$ [36].

\section{Results and Discussion}

\subsection{Microbial Population Analysis}

Total chitin production by crustaceans in marine environments are estimated to reach up to $10^{9}$ t per year [37], and most of the chitin (90\%) is digested within $150 \mathrm{~h}$ in water column [38]. In marine sediments, chitin degradation is slower and the breakdown process is primarily accomplished by indigenous bacteria with capability of digesting chitin extracellularly [39]. Therefore, it is expected that high concentrations of chitin will favor growth and enrichment of certain bacterial groups. In this study, substantial increases of microbial cell numbers associated with chitin amendments were observed after a 28-day incubation (Figure 1). Epifluorescence microscopic counts showed an increase in cell numbers in overlying waters from all treatments containing chitin: CCS, CACS, FCU and FCS. The numbers were from $0.38 \times$ $10^{6}$ cells $/ \mathrm{mL}$ (control) to $3.27 \times 10^{6}, 1.85 \times 10^{6}, 1.08 \times$ $10^{6}, 2.42 \times 10^{6}$ cells $/ \mathrm{mL}$, respectively. However, cell density in the fine-grained sediments in the apatite plus chitin amendments, FACU and FACS, did not demonstrate statistically significant growth compared to the control.

Chitin has been widely used as a bio-control material in soils in order to reduce parasitic diseases. Previous reports showed that chitin amendment was associated with an increase of bacterial populations with chitinolytic activities such as actinomycetes [40-41]. Major breakdown products from chitin are acetate and fructose [20], both of which may serve as carbon sources for anaerobic and facultative microorganisms. Recently, Kanzog and colleagues [18] reported that both microbial numbers and chitinolytic activity significantly increased in the sediment samples enriched with chitin in an experiment conducted in deep-sea sediment, indicating that chitin enhanced microbial growth, enzymatic activity, and population structures, as well. Therefore, chitin may play an important role by providing a slow-release carbon source to maintain microbial activity.

\subsection{Microbial Community Structure}

Several studies have already shown that microbial community structures respond to variations of organic amendments such as chitin $[18,40,41]$. PCR-DGGE in combination with DNA sequencing aided in identifying the predominant bacterial populations and to provide a comprehensive picture of microbial community structure over time and under different amendment and metal conditions. Our study provides a "snapshot" for shift of bacterial population structures under chitin amendments.

Analysis of DGGE band profiles has indicated that

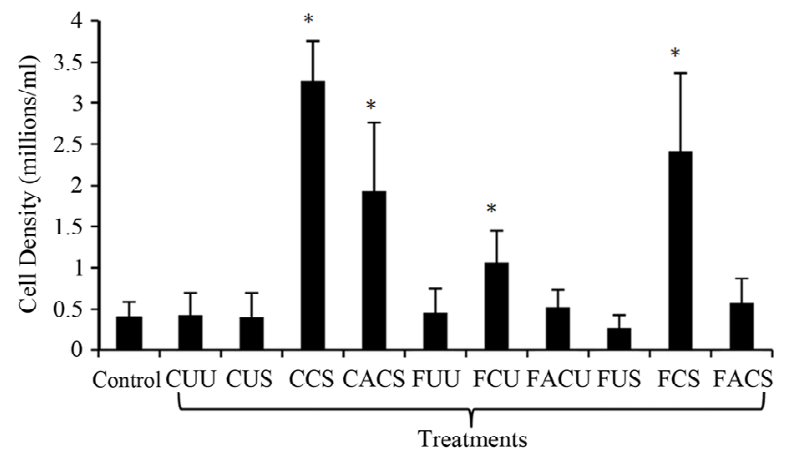

Figure 1. Microscopic cell counts in overlying waters after 28 days incubation. $X$ axis showed the treatments as listed in Table 1. "Significant difference compared to the control (unpaired $t$-test, $p<0.05$ ). Data from treatments CAS, FAU, and FAS were not available.

chitin amendments shifted the bacterial population structures significantly in overlying waters (Figure 2). Phaeobacter (band 1) and Roseobacter (band 2) were the predominant groups in the controls (CUU and FUU), while more distinct bacterial groups were present after chitin and/or apatite treatments in both sediment types (CCS, CACS, FCU, FACU, FCS and FACS, Figures 2 and 3). Most of these enriched bands (No. 5, 6, 8, 9, 10, 12, 14, 15, etc.) belonged to subgroups of Alphaproteobacteria (Figures 2 and 3). However, Betaproteobacteium (Band No. 3 Figure 3), was identified in most samples (CUU, CUS, CAS, FAU, FUS, and FCS). In fact, DGGE profiles from apatite and/or spiked metals were remarkably similar to those from control sediments. Therefore, compared to chitin, addition of apatite or metals had less impact on the bacterial population structures (Figures $\mathbf{2}$ and $\mathbf{3}$ ).

For sediments, more distinct and diverse bacterial groups were enriched in both aerobic/anaerobic interface and anaerobic zone sediments (Figure S1). As an example, in coarse-grained (YB) surface sediments, Bacteroidetes (bands 19, 20), Spirochaetes (band 21), and Roseobacter from Alphaproteobacteria (band 22) were present in both chitin, and chitin + apatite treatments (CCS and CACS, Figures S1(a) and S2). In contrast, Deltaproteobacteria (bands 27, 28) and Bacteroidetes (bands $25,26)$ dominated in anaerobic zone sediments from the same treatments (CCS and CACS, Figures S1(b) \& S2). Due to the detection limit and sensitivity of DGGE approach, treatments from fine sediments (MI) didn't generate distinguishable banding patterns and therefore, we further characterized bacterial community structures by clone library.

As we expected, remarkable population shifts were observed from clone library analyses (Table 2 and Figure 4). Actinobacteria, Alphaproteobacteria, Gammaproteobacteria, Deltaproteobacteria, and Bacteroidetes were predominant groups in unamended fine-grained sediments with spiked metals (FUS). After 28 days in- 
Table 2. Bacterial population structures characterized by clone library. Relative abundance was based on the occurrence of representative sequences. - = not detected.

\begin{tabular}{|c|c|c|c|c|}
\hline \multirow{2}{*}{ Phylum } & \multicolumn{3}{|c|}{ Relative abundance (\%) } & \multirow{2}{*}{ Impact } \\
\hline & FUS & FCS & FACS & \\
\hline Acidobacteria & - & - & 1.9 & Induced \\
\hline Actinobacteria & 20.8 & 8.6 & 3.8 & Decreased \\
\hline Alphaproteobacteria & 22.9 & 14.3 & 13.2 & Decreased \\
\hline Betaproteobacteria & - & 2.9 & 1.9 & Induced \\
\hline Gammaproteobacteria & 22.9 & 10 & 20.8 & Decreased \\
\hline Amphritea & 2.1 & - & 1.9 & \\
\hline Marinobacterium & 2.1 & - & - & \\
\hline Oceanospirillum & 14.6 & 1.4 & - & \\
\hline Paramoritella & - & - & 3.8 & \\
\hline Pseudomonas & 2.1 & - & - & \\
\hline Shewanella & - & - & 1.9 & \\
\hline Uncultured & 2.1 & 8.6 & 13.2 & \\
\hline Deltaproteobacteria & 14.6 & 30 & 28.3 & Decreased \\
\hline Desulfotalea & - & 1.4 & 3.8 & \\
\hline Desulfovibrio & - & 5.7 & 3.8 & \\
\hline Desulfuromonas & - & 5.7 & - & \\
\hline Desulfobacula & - & 1.4 & 1.9 & \\
\hline Geobacter & - & 1.4 & - & \\
\hline Pelobacter & 2.1 & - & - & \\
\hline Uncultured & 12.5 & 14.3 & 18.9 & \\
\hline Epsilonproteobacteria & - & 4.3 & 9.4 & Induced \\
\hline Bacteroidetes & 10.4 & 10 & 11.3 & \\
\hline Chloroflexi & 2.1 & 1.4 & 1.9 & \\
\hline Firmicutes & - & 2.9 & 5.7 & Induced \\
\hline Nitrospirae & 6.3 & 4.3 & - & Decreased \\
\hline Planctomycete & - & 5.7 & - & Induced \\
\hline Rhodospirillaceae & - & - & 1.9 & Induced \\
\hline Spirochaeta & - & 4.3 & - & Induced \\
\hline Verrucomicrobia & - & 1.4 & - & Induced \\
\hline
\end{tabular}

cubation with chitin and chitin + apatite, distinct bacterial groups were induced, including Acidobacteria, Betaproteobacteria, Epsilonproteobacteria, Firmicutes, Planctomycetes, Rhodospirillaceae, Spirochaetes, and Verrucomicrobia, which were not detected in the unamended treatment FUS (Table 2). To date, it is not easy to link the functionality of these bacterial groups with their genetic identification. However, high occurrence of these groups of microorganisms under heavy metal concentrations, e.g. Firmicutes indicated the potential direct or

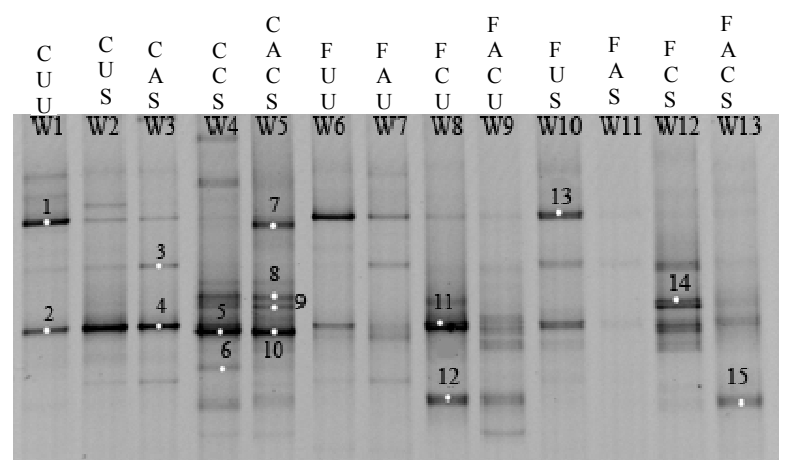

Figure 2. DGGE fingerprints of bacterial community from overlying waters $(W)$. Labels referred to the treatments. Sample FAS failed to obtain PCR products. Bands 1-15 were selected and excised for sequencing.

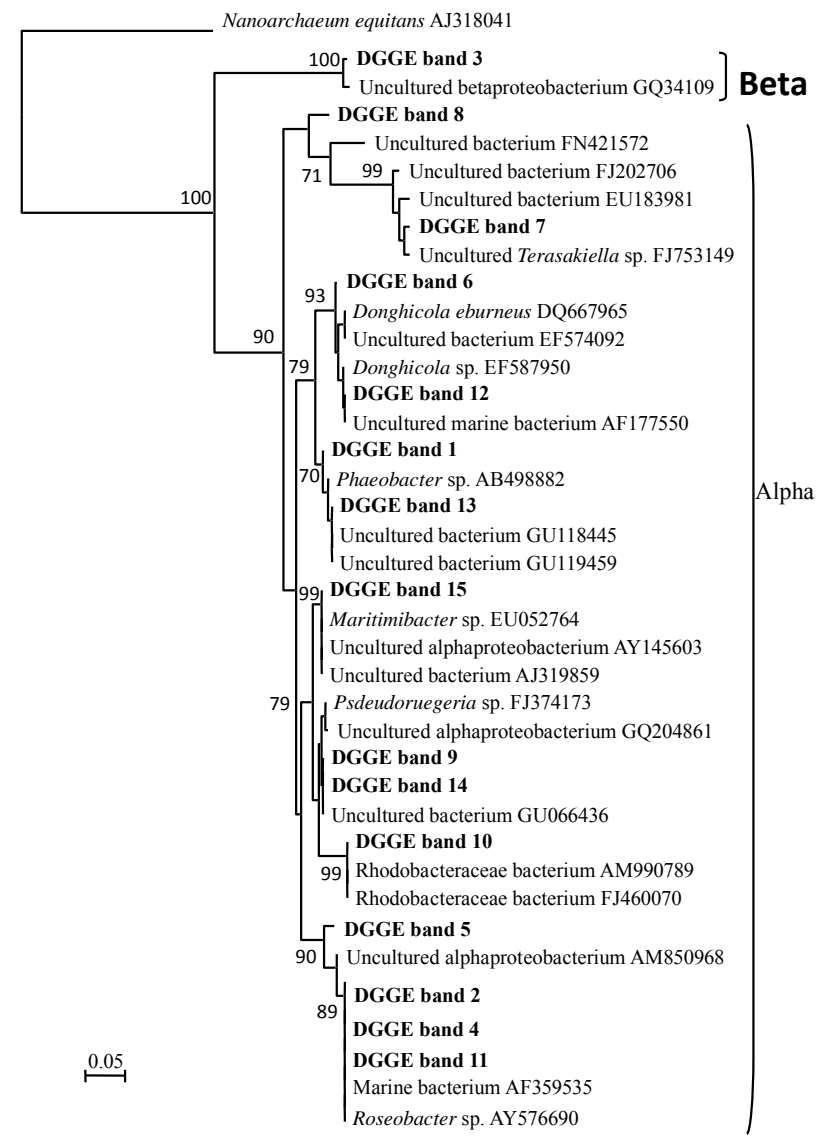

Figure 3. Phylogenetic analysis (DNA distance-NJ) of bacterial DGGE band sequences obtained from overlying waters. Bootstrap values were based on analyses of 1000 resampling of dataset. Nanoarchaeumequitans was used as an outgroup. Scale bar represent 0.05 substitutions per site.

indirect involvement with metal immobilization or bioremediation [42-43]. Further, over time Deltaproteobacteria population increased in abundance, while that of Actinobacteria, Alphaproteobacteria, Nitrospirae decreased (Table 2 and Figure 4). In fact, Deltaproteobacteria became the most dominant groups of bacteria after 

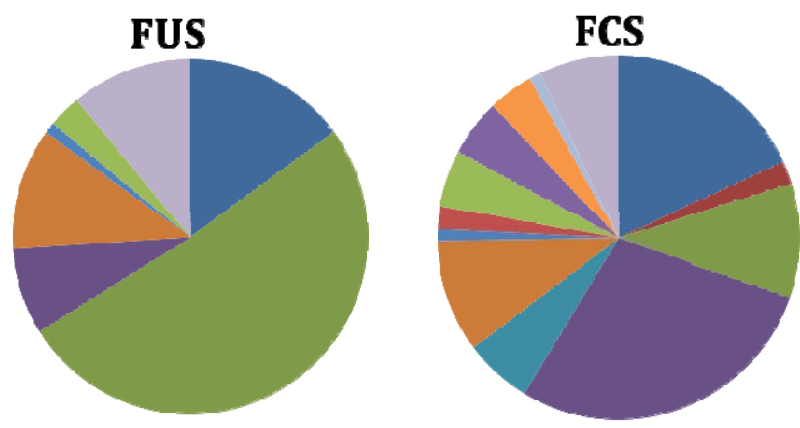

FACS

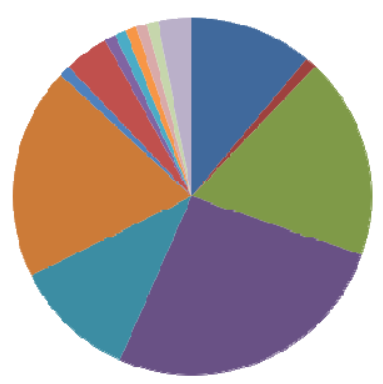

Figure 4. Clone library analyses of bacterial population structures from treatments FUS, FCS and FACS.

28 days incubation in both FCS (30\%) and FAC (28.3\%) (Table 2). Predominant sulfate-reducing bacteria (i.e. Desulfovibrio, Desulfobacula, Desulfotalea) and sulfurreducing bacteria (i.e. Desulfuromonas) sequences were detected in Deltaproteobacteria class. These results agreed with previous observations on increasing sulfate-reducing bacterial communities and activities in response to carbon source amendments [44]. Primarily due to their metabolic end-products such as sulfide, sulfate/sulfur reducing bacteria were able to facilitate metal sequestration and immobilization [24,45]. In addition, these bacteria have been noted for their capability of utilizing metals as electron acceptors via dissimilatory metal reduction [2829]. A good example is Geobacter, which was also retrieved from our clone library analyses from FCS (Table 2). In line with Geobacter, Shewanella of the Gammaproteobacteria class, another recognized metal reducer [46], was also present in the treatment with chitin + apatite (FACS). Both Geobacter and Shewanella have been proven to play critical roles in metal reduction, precipitation and immobilization $[1,23,24,27,45]$. Thus, sulfate/sulfur-reducing bacteria and metal-reducing bacteria responded to chitin and apatite amendments, and were likely responsible for the metal immobilization and sequestration.

Although no significant bacterial cell counts and population shifts were observed in the treatment with apatite alone [30 and this study], apatite held great promise of inducing phosphate-solubilizing bacteria (PSB), which might facilitate the formation of phosphorites, natural

apatite mineral deposits in environments [47-49]. Transition metals in natural environments were expected to be sequestered with phosphates and form more stable metalphosphate complexes and therefore decrease the bioavail ability of these metals [3]. In this study, we tested PSB on agar plates, and positive PSB colonies were present in both overlying water and sediments (Figure S3). The clearing zones indicated solubilization of calcium phosphate from the media (Figure S3). To date, a variety of bacterial groups (e.g. Bacillus, Rhizobium, Pseudomonas, Serratia, Shewanella, Escherichia, Vibrio, and Proteus etc.) have been proven capable of solubilizing phosphate compounds [17,50-51]. Because phosphate is not a limiting factor in open oceans, only few studies have investigated PSB from marine environments [33,51]. However, the presence of common groups of bacteria including Pseudomonas, Shewanella, and Vibrio from our clone libraries suggested that they might respond to apatite amendment and solubilize phosphate in marine sediments.

\subsection{ICP-MS Analysis of Spiked Metals}

In the presence of apatite only, less than $50 \%$ of $\mathrm{Cu}$ and $\mathrm{Cr}$; and $0 \%$ of $\mathrm{Zn}$ were removed from the overlying water in the coarse-grained sediments (CAS; Table 3). A similar effect was observed in the fine-grained sediment as $\mathrm{Cu}$ and $\mathrm{Cr}$ were not removed at all; and in the $\mathrm{Zn}$ sample, $\sim 25 \%$ of $\mathrm{Zn}$ was removed (FAS; Table 3). In the presence of chitin, between $60 \%-100 \%$ of metal removal occurred in the overlying and pore-water (CCS and FCS; Table 3). The combined effect of apatite and chitin in metal removal was similar enough to chitin to demonstrate the important role of chitin in these processes. These data are in agreement with the microbiological data where chitin enhanced microbiological activity versus apatite amendments. The chitin amendments likely stimulated sulfer-transforming bacteria $[30,52]$ and FeS was observed in the mesocosms. In addition, there may have been metal sorption to the chitin particles. However, because chitin is a food source for bacteria, there is the potential when chitin is digested for metal resolubilization. Therefore long-term chitin metal removal should be evaluated. Nevertheless, the role of apatite cannot be excluded as phosphate-solubilizing bacteria were detected. In addition, XAS data also showed the positive effects of apatite in sediments.

\subsection{Effects of Apatite and Chitin Amendment on Zinc Mobilization}

Figure 5 showed an example X-ray absorption near-edge spectroscopy (XAS) spectra on FAU sediments over time post amendment addition and reference spectra of primary components for linear combination fitting (LCF). 
Table 3. Metal removal from the overlying water $(\mathrm{OW})$ and pore-water (PW) samples relative to controls.

\begin{tabular}{ccccccc}
\hline & \multicolumn{3}{c}{ Metal removal, \%, } & Metal removal, \%, PW \\
\hline $\begin{array}{c}\text { Coarse-grained (YB) } \\
\text { sediment }\end{array}$ & $\mathrm{Cu}$ & $\mathrm{Cr}$ & $\mathrm{Zn}$ & $\mathrm{Cu}$ & $\mathrm{Cr}$ & $\mathrm{Zn}$ \\
Apatite (CAS) & 40 & 45 & 0 & $\mathrm{NA}^{*}$ & $\mathrm{NA}$ & $\mathrm{NA}$ \\
Chitin (CCS) & 60 & 100 & 85 & $\mathrm{NA}$ & $\mathrm{NA}$ & $\mathrm{NA}$ \\
Apatite + chitin (CACS) & 70 & 100 & 57 & $\mathrm{NA}$ & $\mathrm{NA}$ & $\mathrm{NA}$ \\
$\begin{array}{c}\text { Fine-grained (MI) } \\
\text { sediment }\end{array}$ & & & & & & \\
Apatite (FAS) & 0 & 0 & 24 & 70 & 75 & 45 \\
Chitin (FCS) & 62 & 98 & 65 & 87 & 97 & 63 \\
Apatite + chitin (FACS) & 47 & 100 & 42 & 0 & 68 & 49 \\
\hline
\end{tabular}

"NA $=$ not analyzed. Pore water was not extractable from these sandy samples.

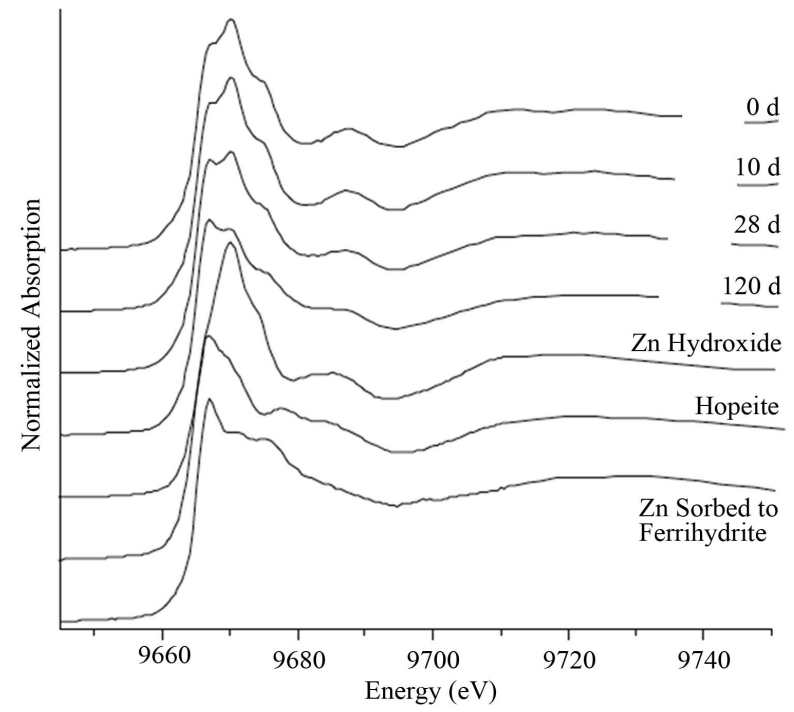

Figure 5. Normalized Ka Zn X-ray absorption spectra of FAU sediments over time post amendment addition and reference spectra of primary components for linear combination fitting.

Due to concentration of $\mathrm{Cu}$ and $\mathrm{Cr}$, as well as detector issues during data collection, only spectra for $\mathrm{Zn}$ were collected. The coarse samples also provided complications for data collection due to the low sorption capacity of sand. Most metals do not sorb to sand, as they tend to prefer clay minerals and organic matter due to surface charges. Only treatments FAU, FUS, FAS, FCS and FACS at certain time points were run on the XAS, and the $\mathrm{Zn}$ XAS linear combination fitting results were shown in Table 4. Principal component analysis (PCA) identified and confirmed LCF validity with five suitable components: $\mathrm{Zn}$ hydroxide, $\mathrm{Zn}$ Carbonate, $\mathrm{Zn}$ orbed to ferrihydrite, $\mathrm{ZnAl}_{2} \mathrm{O}_{4}$, and $\mathrm{Zn}_{3}\left(\mathrm{PO}_{4}\right)_{2}$ (hopeite).
At day 0 , sediments from apatite amended unspiked treatment (FAU) was identified by XAS to contain primarily easily mobile zinc phases; i.e., zinc hydroxide, $\mathrm{Zn}$ carbonate, $\mathrm{Zn}$ sorbed to ferrihydrite, $\mathrm{ZnAl}_{2} \mathrm{O}_{4}$, and some initial $\mathrm{Zn}_{3}\left(\mathrm{PO}_{4}\right)_{2}$. By day 28 and 120, a significant transition to sorbed $\mathrm{Zn}$ and zinc phosphate was observed in the presence of the apatite (Table 3). For spiked sediments, again the predominant initial $\mathrm{Zn}$ species is zinc hydroxide phases (Table 3). Unamended treatment (FUS) showed no significant changes from easily mobile $\mathrm{Zn}$ hydroxide phase to a more insoluble $\mathrm{Zn}$ phosphate. However, remarkable changes occurred after 28 days post apatite amendment (FAS) (Table 3), indicating the apatite effectively immobilized and sequestered $\mathrm{Zn}$. Chitin amendments affected the $\mathrm{Zn}$ speciation even further: 1) $\sim 13 \%$ hopeite (from zero) in the day 10 formed in chitin amended sample (FCS) while notable $\mathrm{Zn}$ hydroxide phase decreased from $\sim 63 \%$ to $55 \%$; 2) In the apatite + chitin (FACS), hopeite was observed at day 0 post mixing ( 9\%), and increased to $27 \%$ by Day 10 (Table 3). Therefore, chitin alone does aid in the transition of soluble zinc to the immobilized phase of hopeite; but the combined effect of chitin and apatite increased the immobilization by a factor of 2 .

\section{Conclusion}

The apatite plus chitin amendment increased the microbial cell densities and significantly altered the bacterial population structures (Figures 1 and 4, Table 2). For example, growth of Firmicutes was induced, and relative abundance of Deltaproteobacteria was significantly increased compared to the control (FUS) (Table 2). Deltaproteobacteria and Firmicutes have both been proven to be capable of producing sulfides and carbonates that quickly bind bioavailable metals. Further, phosphate from the apatite amendments was solubilized biotically or abiotically. These soluble phosphates sequestered metals and formed more thermodynamically stable metal phosphates. Therefore, we conclude that certain groups of microorganisms (e.g. Deltaproteobacteria, Firmicutesand phosphate-solubilizing bacteria) were induced by amendments of chitin and apatite, and that these microorganisms worked collaboratively and helped facilitate the transformation and immobilization of the heavy metals. Thus, the mixed apatite and chitin amendments may provide an ideal and cost-effective approach for efficient and permanent metal sequestration in marine sediments. These in-situ remedial options show the potential for more cost effective remediation compared to conventional $e x$-situ options such as dredging.

\section{Acknowledgements}

The Strategic Environmental Research and Development 
Table 4. Linear combination fitting of fine-grained sediments (Mare Island Naval Shipyard). Treatments FAU, FUS, FAS, FCS, and FACS were shown in Table 1. - = not detected. The $R$ factor is the error (\%) associated with the fits.

\begin{tabular}{|c|c|c|c|c|c|c|c|c|c|}
\hline \multirow{2}{*}{ Treatments } & \multirow{2}{*}{ Amendment } & \multirow{2}{*}{ Metal mixture } & \multirow{2}{*}{ Reaction time } & \multicolumn{5}{|c|}{ Linear contribution fitting distribution $(\%)$} & \multirow{2}{*}{$\begin{array}{c}\mathrm{R} \text { factor } \\
(\%)\end{array}$} \\
\hline & & & & $Z_{n}$ hydroxide ${ }^{1}$ & Zn carbonate & Sorbed $\mathrm{Zn}^{2}$ & $\mathrm{ZnAl}_{2} \mathrm{O}_{4}$ & Hopeite $^{3}$ & \\
\hline \multirow[t]{3}{*}{ FAU } & $5 \%$ apatite & Unspiked & 0 days & 59.1 & 7.4 & 9.5 & 18.8 & 5.4 & 3.00 \\
\hline & & & 10 days & 59.1 & 7.9 & 8.5 & 18.5 & 6.2 & 2.95 \\
\hline & & & 28 days & 43.4 & 8.4 & 18.2 & 12.9 & 17.2 & 1.50 \\
\hline \multirow[t]{3}{*}{ FUS } & None & Spiked & 0 days & 71.0 & 10.0 & 19.0 & - & - & 1.61 \\
\hline & & & 10 days & 70.0 & 10.0 & 18.0 & - & - & 1.94 \\
\hline & & & 28 days & 70.0 & - & 30.0 & - & - & \\
\hline \multirow[t]{3}{*}{ FAS } & $5 \%$ apatite & Spiked & 0 days & 45.0 & 16.0 & - & 14.0 & 25.0 & \\
\hline & & & 10 days & 43.0 & 14.0 & - & 15.0 & 28.0 & \\
\hline & & & 28 days & 31.0 & 9.0 & 26.0 & - & 34.0 & \\
\hline \multirow[t]{2}{*}{ FCS } & $0.5 \%$ chitin & Spiked & 0 days & 63.0 & 25.0 & - & 13.0 & - & 1.12 \\
\hline & & & 10 days & 55.0 & 17.0 & 5.0 & 11.0 & 13.0 & 1.07 \\
\hline \multirow[t]{2}{*}{ FACS } & $5 \%$ apatie $+0.5 \%$ chitin & Spiked & 0 days & 68.0 & 13.0 & - & 10.0 & 9.0 & 1.97 \\
\hline & & & 10 days & 52.0 & 15.0 & - & 8.0 & 27.0 & 0.97 \\
\hline
\end{tabular}

${ }^{1}$ Includes $\mathrm{Zn}(\mathrm{OH})_{2}$ and related layered double hydroxides; ${ }^{2} \mathrm{Zn}$ sorbed to ferrihydrite; ${ }^{3} \mathrm{Zn}_{3}\left(\mathrm{PO}_{4}\right)_{2}$.

Program (SERDP) funded this research under project \#ER-1551. The authors thank Gunther Rosen, Ryan Halonen, Brandon Swope, and Ignacio Rivera for sampling and technical support. Although EPA contributed to this article, the research presented was not performed by or funded by EPA and was not subject to EPA's quality system requirements. Consequently, the views, interpretations, and conclusions expressed in this article are solely those of the authors and do not necessarily reflect or represent EPA's views or policies.

\section{REFERENCES}

[1] R. T. Anderson, H. A. Vrionis, I. Ortiz-Bernad, C. T. Resch, P. E. Long, R. Dayvault, K. Karp, S. Marutzky, D. R. Metzler, R. Peacock, D. C. White, M. Lowe and D. R. Lovley, "Stimulating the in Situ Activity of Geobacter Species to Remove Uranium from the Groundwater of a Uranium-Contaminated Aquifer," Applied and Environmental Microbiology, Vol. 69, No. 10, 2003, pp. 58845891. doi:10.1128/AEM.69.10.5884-5891.2003

[2] B. Sharma, K. H. Gardner, J. Melton, A. Hawkins and G. Tracey, "Evaluation of Activated Carbon as a Reactive Cap Sorbent for Sequestration of Polychlorinated Biphenyls in the Presence of Humic Acid," Environmental Engineering Science, Vol. 26, No. 9, 2009, pp. 13711379. doi:10.1089/ees.2008.0231

[3] S. Brown, R. Chaney, J. Hallfrisch, J. A. Ryan and W. R. Berti, "In Situ Soil Treatments to Reduce the Phyto and Bioavailability of Lead, Zinc, and Cadmium," Journal of Environmental Quality, Vol. 33, No. 2, 2004, pp. 522-531. doi:10.2134/jeq2004.0522
[4] J. D. Istok, J. M. Senko, L. R. Krumholtz, D. Watson, M. A. Bogle, A. Peacock, Y. J. Chang and D. C. White, "In Situ Bioreduction of Technetium and Uranium in a Nitrate Contaminated Aquifer," Environmental Science \& Technology, Vol. 38, No. 2, 2004, pp. 468-475. doi:10.1021/es034639p

[5] T. P. Seager, and K. H. Gardner, "Barriers to Adoption of Novel Environmental Technologies: Contaminated Sediments," In: E. Levner, I. Linkov and J. M. Proth, Eds., Strategic Management of Marine Ecosystems, Springer, 2005, pp. 298-312. doi:10.1007/1-4020-3198-X_16

[6] C. J. Werth, R. A. Sanford, R. St John and G. C. Barnuevo, "Long-Term Management of Chlorinated Solvent Plumes Using a Slow-Release in Situ Electron Donor Source," Abstract poster G-4. In: SERDP/ESTCP Meeting, Washington DC, 2005.

[7] H. Paller and A.S. Knox, "Amendments for the in Situ Remediation of Contaminated Sediments: Evaluation of Potential Environmental Impacts," Science of the Total Environment, Vol. 408, No. 20, 2010, pp. 4894-4900. doi:10.1016/j.scitotenv.2010.06.055

[8] Y. J. Chang, P. E. Long, R. Geyer, A. D. Peacock, C. T. Resch, K. Sublette, S. Pfiffner, A. Smithgall, R. T. Anderson, H. A. Vrionis, J. R. Stephen, R. Dayvault, I. OrtizBernad, D. R. Lovley and D. C. White, "Microbial Incorporation of 13Clabeled Acetate at the Field Scale: Detection of Microbes Responsible for Reduction of U(VI)," Environmental Science \& Technology, Vol. 39, No. 23, 2005, pp. 9039-9048. doi:10.1021/es051218u

[9] S. Lukas and J. T. Hollibaugh, "Response of Sediment Bacterial Assemblages to Selenate and Acetate Amendments," Environmental Science \& Technology, Vol. 35, No. 3, 2001, pp. 528-534. doi:10.1021/es001492i 
[10] Q. Y. Ma, T. J. Logan and S. J. Traina, "Lead Immobilization from Aqueous Solutions and Contaminated Soils Using Phosphate Rocks," Environmental Science \& Technology, Vol. 29, No. 4, 1995, pp. 1118-1126. doi:10.1021/es00004a034

[11] S. Knox, D. I. Kaplan and M. H. Paller, "Phosphate Sources and Their Suitability for Remediation of Contaminated Soils," Science of the Total Environment, Vol. 357, No. 1-3, 2006, pp. 271-279. doi:10.1016/j.scitotenv.2005.07.014

[12] X. D. Cao, L. Q. Ma and A. Wahbi, "Immobilization of $\mathrm{Cu}, \mathrm{Zn}$, and $\mathrm{Pb}$ in Contaminated Soils Using Phosphate Rock and Phosphoric Acid," Journal of Hazardous Materials, Vol. 164, No. 2-3, 2009, pp. 555-564. doi:10.1016/j.jhazmat.2008.08.034

[13] Q. Y. Ma, S. Traina, T. Logan and J. Ryan, "In Situ Lead Immobilization by Apatite," Environmental Science \& Technology, Vol. 27, No. 9, 1993, pp. 1803-1810. doi:10.1021/es00046a007

[14] J. Wright, K. R. Rice, B. Murphy and J. Conca, "PIMS Using Apatite IITM: How It Works To Remediate Soil and Water," In: R. E. Hinchee and B. Alleman, Eds., Sustainable Range Management, Battelle Press, Columbus, 2004.

[15] U. Ghosh, R. G. Luthy, G. Cornelissen, D. Werner and C. A. Menzie, "In-Situ Sorbent Amendments: A New Direction in Contaminated Sediment Management," Environmental Science \& Technology, Vol. 45, No. 4, 2011, pp. 1163-1168. doi:10.1021/es102694h

[16] G. B. Williams, K. G. Scheckel, G. McDermott, D. Gratson, D. Neptune and J. A. Ryan, "Speciation and Bioavailability of Zinc in Amended Sediments," Chemical Speciation and Bioavailability, Vol. 23, No. 3, 2011, pp. 143-154. doi:10.3184/095422911X13103699236851

[17] B. Uzair and N. Ahmed, "Solubilization of Insoluble Inorganic Phosphate Compounds by Attached and FreeLiving Marine Bacteria," Journal of Basic \& Applied Sciences, Vol. 3, No. 2, 2007, pp. 59-63.

[18] C. Kanzog, A. Ramette, N. V. Queric and M. Klages, "Response of Benthic Microbial Communities to Chitin Enrichment: An in Situ Study in the Deep Arctic Ocean," Polar Biology, Vol. 32, No. 1, 2008, pp. 105-112. doi:10.1007/s00300-008-0510-4

[19] A. Boetius and K. Lochte, "Effect of Organic Enrichments on Hydrolytic Potentials and Growth of Bacteria in Deep-Sea Sediments," Marine Ecology Progress Series, Vol. 140, 1996, pp. 239-250. doi:10.3354/meps140239

[20] B. L. Bassler, C. Yu, Y. C. Lee and S. Roseman, "Chitin Utilization by Marine Bacteria: Degradation and Catabolism of Chitin Oligosaccharides by Vibrio furnissii," Journal of Biological Chemistry, Vol. 266, No. 36, 1991, pp. 24276-24286.

[21] L. Brierley, "Metal Immobilization Using Bacteria," In: H. L. Ehrlich and C. L. Brierley, Eds., Microbial Mineral Recovery, McGraw-Hill, 1990, pp. 303-323.

[22] B. M. Tebo, "Metal Precipitation by Marine Bacteria: Potential for Biotechnological Applications," In: J. K. Setlow, Ed., Genetic Engineering, Plenum Press, 1995, pp. 231-261.
[23] R. Lovley, "Dissimilatory Metal Reduction," Annual Review of Microbiology, Vol. 47, 1993, pp. 263-290. doi:10.1146/annurev.mi.47.100193.001403

[24] L. J. Barnes, P. J. M. Scheeren and C. J. N. Buisman, "Microbial Removal of Heavy Metal and Sulfate from Contaminated Groundwaters," In: J. L. Means and R. E. Hinchee, Eds., Emerging Technology for Bioremediation of Metals, CRC Press, 1994, pp. 38-49.

[25] L. L. Barton and F. A. Tomei, "Characteristics and Activities of Sulfate-Reducing Bacteria," In: L. L. Barton, Ed., Sulfate-Reducing Bacteria, Plenum Press, 1995, pp. 1-32. doi:10.1007/978-1-4899-1582-5_1

[26] R. T. Anderson and D. R. Lovley, "Ecology and Biogeochemistry of in Situ Groundwater Bioremediation," In: J. G. Jones, Ed., Advances in Microbial Ecology, Plenum Press, 1997, pp. 289-350. doi:10.1007/978-1-4757-9074-0 7

[27] K. H. Nealson, "Sediment Bacteria: Who's There, What Are They Doing, and What's New?" Annual Review of Earth and Planetary Sciences, Vol. 25, 1997, pp. 403-434. doi:10.1146/annurev.earth.25.1.403

[28] B. M. Tebo and A. Y. Obraztsova, "Chromium(VI), Manganese(IV), Uranium(VI), and Iron(III): Electron Acceptors for Growth for a Novel Spore Forming Sulfate Reducing Bacterium," FEMS Microbiology Letters, Vol. 162, No. 1, 1998, pp. 193-198. doi:10.1111/j.1574-6968.1998.tb12998.x

[29] Y. M. Arias and B. M. Tebo, "Comparative Studies of $\mathrm{Cr}(\mathrm{VI})$ Reduction by Sulfidogenic and Non-Sulfidogenic Microbial Communities," Applied and Environmental Microbiology, Vol. 69, No. 3, 2003, pp. 1847-1853. doi:10.1128/AEM.69.3.1847-1853.2003

[30] J. Kan, Y. Wang, A. Obraztsova, G. Rosen, J. Leather, K. G. Scheckel, K. H. Nealson and Y. M. Arias-Thode, "Marine Microbial Community Response to Inorganic and Organic Sediment Amendments in Laboratory Mesocosms," Ecotoxicology and Environmental Safety, Vol. 74, No. 7, 2011, pp. 1931-1941. doi:10.1016/j.ecoenv.2011.06.011

[31] G. Rosen, J. Leather, J. Kan and Y. M. Arias-Thode, "Ecotoxicological Response of Marine Organisms to Inorganic and Organic Sediment Amendments in Laboratory Exposures," Ecotoxicology and Environmental Safety, Vol. 74, No. 7, 2011, pp. 1921-1930. doi:10.1016/j.ecoenv.2011.06.023

[32] T. Huber, G. Faulkner and P. Hugenholtz, "Bellerophon; A Program to Detect Chimeric Sequences in Multiple Sequence Alignments," Bioinformatics, Vol. 20, No. 14, 2004, pp. 2317-2319. doi:10.1093/bioinformatics/bth226

[33] K. Ayyakkannu and D. Chandramohan, "Occurrence and Distribution of Phosphate Solubilizing Bacteria and Phosphatase in Marine Sediments at Porto Novo," Marine Biology, Vol. 11, No. 3, 1971, pp. 201-205. doi:10.1007/BF00401268

[34] J. Talbot and A. Weiss, "Laboratory Methods for ICP-MS Analysis of Trace Metals in Precipitation," 1994. http://nsdi.epa.gov/glnpo/lmmb/methods/icmsmeth.pdf

[35] S. E. Bufflap and H. E. Allen, "Comparison of Pore Water Sampling Techniques for Trace Metals," Water Research, Vol. 29, No. 9, 1995, pp. 2051-2054. 


\section{doi:10.1016/0043-1354(95)00032-G}

[36] G. Scheckel, J. A. Ryan, D. Allen and N. V. Lescano, "Determining Speciation of $\mathrm{Pb}$ in Phosphate-Amended Soils: Method Limitations," Science of the Total Environment, Vol. 350, No. 1-3, 2005, pp. 261-272. doi:10.1016/j.scitotenv.2005.01.020

[37] H. M. Cauchie, "Chitin Production by Arthropods in the Hydrosphere," Hydrobiology, Vol. 470, No. 1-3, 2002, pp. 63-96. doi:10.1023/A:1015615819301

[38] M. Poulicek and C. Jeuniaux, "Chitin Biodegradation in Marine Environments: An Experimental Approach," Biochemical Systematics and Ecology, Vol. 19, No. 5, 1991, pp. 385-394. doi:10.1016/0305-1978(91)90055-5

[39] J. W. Deming and J. A. Baross, "The Early Diagenesis of Organic Matter: Bacterial Activity," In: M. H. Engel and S. A. Macko, Eds., Organic Geochemistry: Principles and Application, Plenum Press, New York, 1993, pp. 119-144. doi:10.1007/978-1-4615-2890-6 5

[40] A. Bell, J. C. Hubbard, L. Liu, R. M. Davis and K. V. Subbarao, "Effects of Chitin and Chitosan on the Incidence and Severity of Fusarium Yellows in Celery," Plant Disease, Vol. 82, No. 3, 1998, pp. 322-328. doi:10.1094/PDIS.1998.82.3.322

[41] J. Hallmann, R. Rodriguez-Kabana and J. W. Kloepper, "Chitin-Mediated Changes in Bacterial Communities of the Soil, Rhizosphere and within Roots of Cotton in Relation to Nematode Control," Soil Biology and Biochemistry, Vol. 31, No. 4, 1999, pp. 551-560. doi:10.1016/S0038-0717(98)00146-1

[42] D. M. Akob, H. J. Mills and J. E. Kostka, "Metabolically Active Microbial Communities in Uranium-Contaminated Subsurface Sediment," FEMS Microbiology Ecology, Vol. 59, No. 1, 2006, pp. 95-107. doi:10.1111/j.1574-6941.2006.00203.x

[43] G. Garau, P. Castaldi, L. Santona, P. Deiana and P. Melis, "Influence of Red Mud, Zeolite and Lime on Heavy Metal Immobilization, Culturable Heterotrophic Microbial Populations and Enzyme Activities in a Contaminated Soil," Geoderma, Vol. 142, No. 1-2, 2007, pp. 4757. doi:10.1016/j.geoderma.2007.07.011
[44] J. Kleikemper, O. Pelz, M. H. Schroth and J. Zeyer, "Sulfate-Reducing Bacterial Community Response to Carbon Source Amendments in Contaminated Aqufer Microcosms," FEMS Microbiology Ecology, Vol. 42, No. 1, 2002, pp. 109-118. doi:10.1111/j.1574-6941.2002.tb01000.x

[45] L. L. Barton and G. D. Fauque, "Biochemistry, Physiology and Biotechnology of Sulfate-Reducing Bacteria," Advances in Applied Microbiology, Vol. 68, 2009, pp. 41-98. doi:10.1016/S0065-2164(09)01202-7

[46] C. Myers and K. H. Nealson, "Bacterial Manganese Reduction and Growth with Manganese Oxide as the Sole Electron Acceptor," Science, Vol. 240, No. 4857, 1988, pp. 1319-1321. doi:10.1126/science. 240.4857 .1319

[47] G. N. Baturin, "Some Unique Sedimentological and Geochemical Features of Deposits in Coastal Upwelling Regions," In: J. Thiede and E. Suess, Eds., Coastal Upwelling, Plenum Press, 1983, pp. 11-27. doi:10.1007/978-1-4613-3709-6 2

[48] C. E. Reimers, M. Kastner and R. E. Garrison, "The Role of Bacterial Mats in Phosphate Mineralization with Particular Reference to the Monterey Formation," In: W. C. Burnett and S. R. Riggs, Eds., Phosphate Deposits of the World, Cambridge University Press, 1990, pp. 300-311.

[49] N. Schulz and H. D. Schulz, "Large Sulfur Bacteria and the Formation of Phosphorite," Science, Vol. 307, 2005, pp. 416-418. doi:10.1126/science. 1103096

[50] H. Rodriguez and R. Fraga, "Review: Phosphate Solubilizing Bacteria and Their Role in Plant Growth Promotion," Biotechnology Advances, Vol. 17, No. 4-5, 1999 , pp. 319-339. doi:10.1016/S0734-9750(99)00014-2

[51] D. De Souza, S. Nair and D. Chandramohan, "Phosphate Solubilizing Bacteria around Indian Peninsula," Indian Journal of Marine Sciences, Vol. 29, 2000, pp. 48-51.

[52] A. Robinson-Lora and R. A. Brennan, "Efficient Metal Removal and Neutralization of Acid Mine Drainage by Crab-Shell Chitin under Batch and Continuous Flow Conditions," Bioresource Technology, Vol. 100, No. 21, 2009, pp. 5063-5071. doi:10.1016/j.biortech.2008.11.063 


\section{Supplementary}

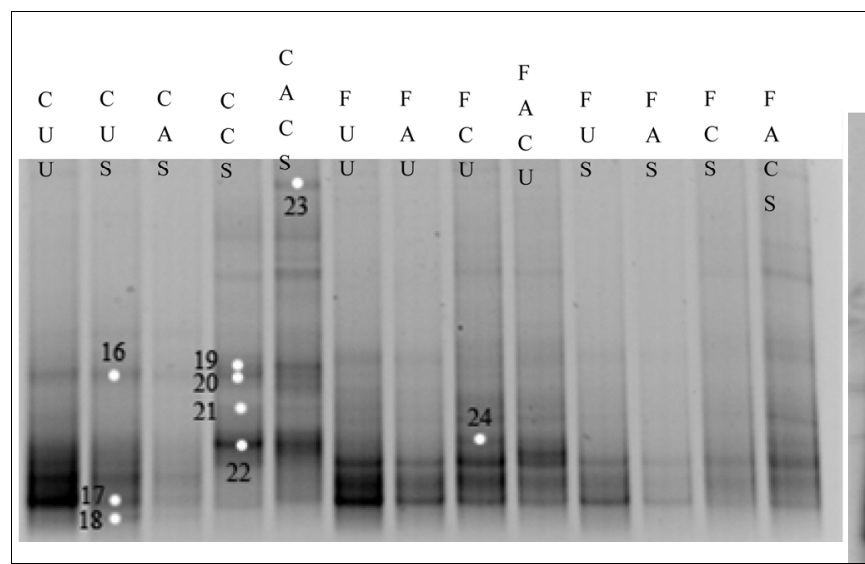

(a)

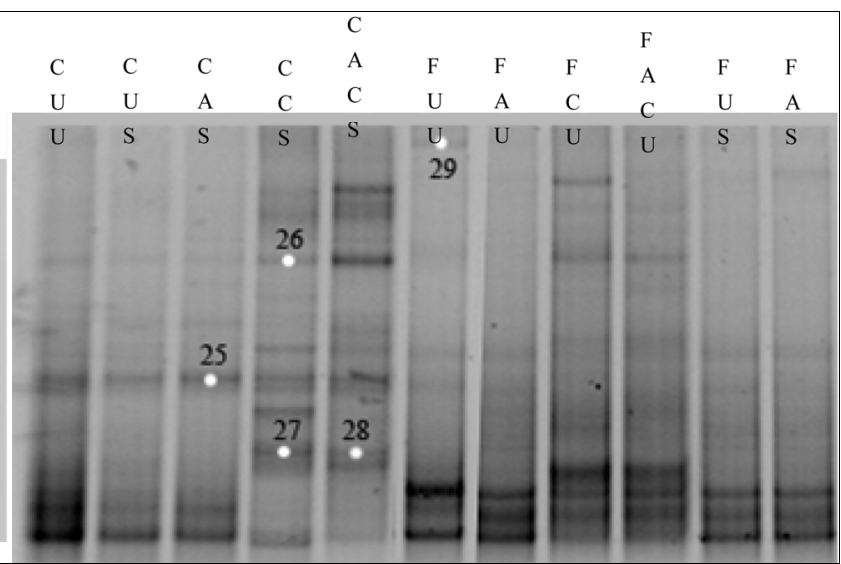

(b)

Figure S1. DGGE fingerprints of bacterial community from aerobic/anaerobic interface (a) and anaerobic zone (b) sediments. Labels referred to the corresponding treatments as listed in Table 1. Bands 16-29 were selected and excised for sequencing. Anaerobic sediment samples from treatments FCS and FACS were not available (b).

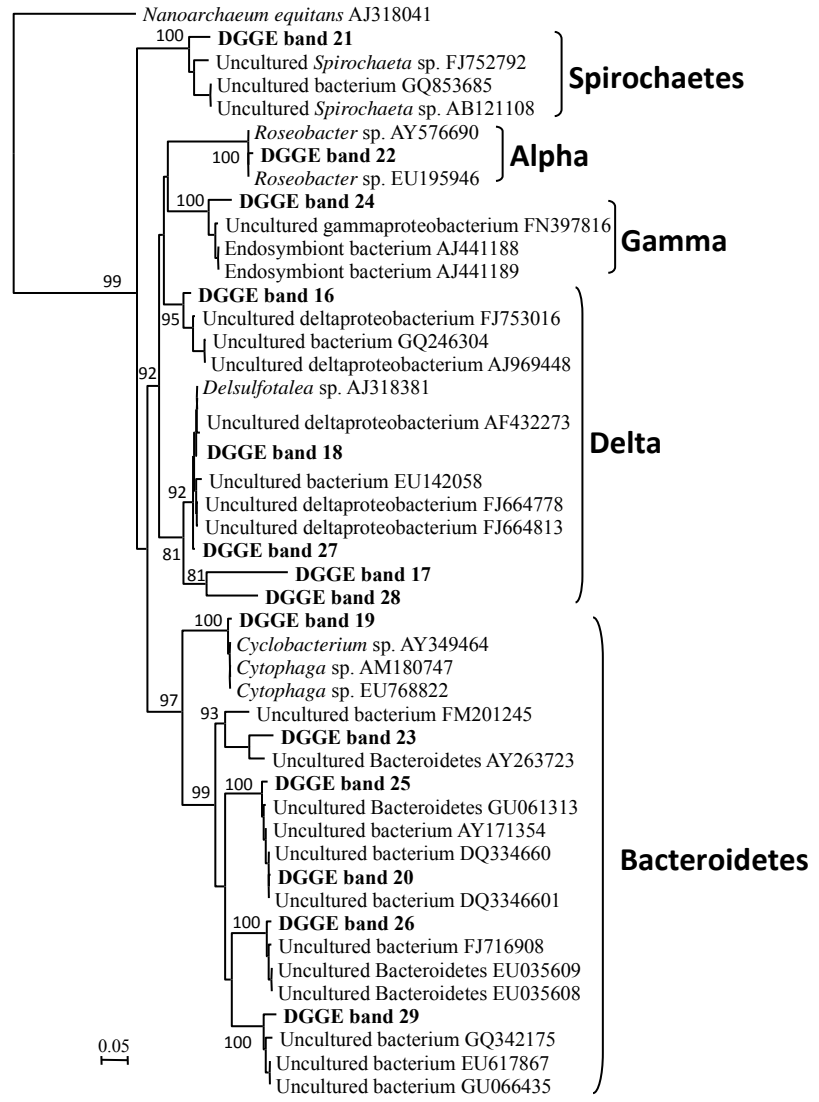

Figure S2. Phylogenetic analysis (DNA distance-NJ) of bacterial DGGE band sequences obtained from Supplementary Figure 2. Alpha, Gamma, and Delta represent subdivisions of Proteobacteria. Bootstrap values were based on 1000 replicated trees. Nanoarchaeumequitans was used as an outgroup. Scale bar represent 0.05 substitutions per site.

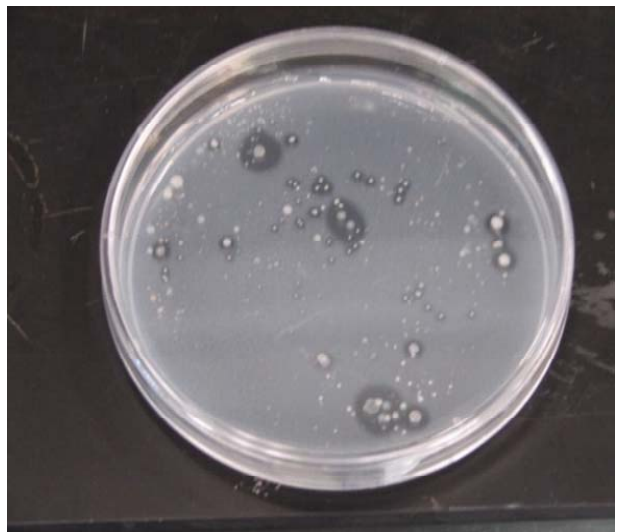

(a)

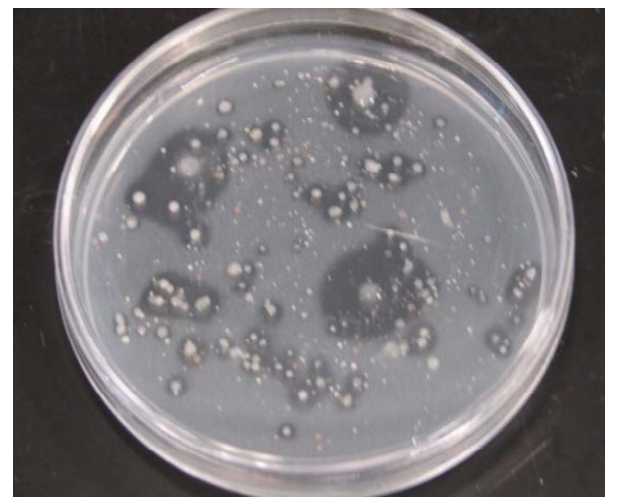

(b)

Figure S3. PSB (phosphate solubilizing bacteria) cultures after 2 weeks incubation. Clearing zones showed bacterial solubilization of calcium phosphate. Left: FAS treatment with $10^{-4}$ dilution; Right: FACS treatment with $10^{-4}$ dilution. 